\title{
A survey of digital rectal examination training in Canadian medical schools
}

\author{
Alysha Nensi BScH, Nilesh Chande MD FRCPC
}

A Nensi, N Chande. A survey of digital rectal examination training in Canadian medical schools. Can J Gastroenterol 2012;26(7):441-444.

BACKGROUND: The digital rectal examination (DRE) is important for the diagnosis of a variety of gastrointestinal, urological and gynecological disorders. However, it appears that Canadian medical students may not be adequately taught nor provided the opportunity to practice their skills often enough. The present study was an analysis of the current practices in DRE teaching and evaluation in undergraduate medicine programs across Canada.

METHODS: Clinical skills coordinators from the 14 English-speaking medical schools in Canada were invited to participate in the survey and to respond to questions regarding DRE teaching at their respective schools.

RESULTS: Thirteen of the 14 schools (93\%) responded to the survey. The DRE is taught in various ways: $69 \%$ of schools use anatomical rectal models, $62 \%$ use video tutorials and $62 \%$ involve physician instruction. Most schools (85\%) offer one formal teaching session before clerkship. Generally, there is no formal DRE teaching session during clerkship. Preclerkship students in $62 \%$ of the schools perform $\leq 1$ DRE during their training, and clinical skills coordinators in $85 \%$ of the schools expected that clerkship students perform $\leq 2$. The training is evaluated in a variety of ways, with most schools (77\%) only requiring mandatory attendance.

DISCUSSION: Although a variety of techniques are used to teach and evaluate DRE training in Canadian medical schools, students are performing very few DREs before graduation. Medical schools should objectively evaluate proficiency to give meaningful feedback and improve competence in their students as well as provide more opportunities for students to obtain the necessary experience performing DREs during their clinical training.

Key Words: Digital rectal examination; Gastroenterology; Medical education

$\mathrm{T}$ he digital rectal examination (DRE), a common physical examination manoeuvre, is important for the diagnosis of a variety of gastrointestinal, urological and gynecological disorders. While the DRE is a standard part of a complete physical examination, recent literature suggests that it is significantly underperformed in clinical practice, even in academic centres. In one study, less than onequarter of patients presenting with urological symptoms received a DRE before referral to a specialist (1), while another study reported that more than $80 \%$ of patients admitted to hospital did not undergo a documented DRE (2). This underperformance has been attributed to a variety of reasons, with one of the most common being low comfort level among residents and medical students with performing the examination due to lack of adequate education and practice (3-5). A report of the attitudes and behaviours of medical students and recent medical graduates suggested that $<30 \%$ of students routinely performed DREs on physical examination (6). Another study demonstrated that one-half of graduating fourth-year students had never

\section{Un sondage sur la formation au toucher rectal dans les facultés de médecine canadiennes}

HISTORIQUE : Il est important de maîtriser le toucher rectal pour diagnostiquer divers troubles gastro-intestinaux, urologiques et gynécologiques. Cependant, il semble que les étudiants en médecine canadiens ne reçoivent peut-être pas la formation pertinente ou n'aient pas l'occasion d'exercer leurs habiletés assez souvent. La présente étude était une analyse des pratiques courantes dans l'enseignement et l'évaluation du toucher rectal dans le cadre de programmes de médecine du premier cycle au Canada.

MÉTHODOLOGIE : Les coordonnateurs des habiletés cliniques de 14 facultés de médecine anglophones du Canada ont été invités à participer au sondage et à répondre à des questions sur l'enseignement du toucher rectal dans leur faculté respective.

RÉSULTATS : Treize des 14 facultés (93\%) ont répondu au sondage. Le toucher rectal est enseigné de diverses façons : $69 \%$ utilisent des modèles rectaux anatomiques, $62 \%$, des tutoriels vidéo et $62 \%$,les directives de médecins. La plupart des facultés (85\%) offrent une séance d'enseignement classique avant le stage. En général, il n’y a pas de telle séance pendant le stage. Dans 62 \% des facultés, les étudiants qui n'ont pas encore fait de stage effectuent un maximum d'un toucher rectal pendant leur formation, et les coordonnateurs des habiletés cliniques de $85 \%$ des facultés s'attendaient qu'ils en effectuent un maximum de deux.La formation est évaluée de diverses façons, la plupart des facultés (77\%) exigeant seulement une présence obligatoire.

EXPOSÉ : Même si diverses techniques sont utilisées pour enseigner et évaluer la formation au toucher rectal dans les facultés de médecine canadiennes, les étudiants en effectuent très peu avant d'obtenir leur diplôme. Les facultés de médecine devraient procéder à une évaluation objective de leur capacité de donner des commentaires significatifs et d'améliorer les compétences de leurs étudiants, de même que de leur fournir plus d'occasions d'acquérir l'expérience nécessaire pour effectuer des touchers rectaux pendant leur formation clinique.

performed a DRE during their clerkship and $86 \%$ had never palpated a malignant prostate (7).

The DRE is an essential part of a physical examination and, should therefore, be included as part of the medical school clinical skills curriculum; however, it appears that students are not being adequately formally taught nor being provided the opportunity to practice their skills often enough to have the confidence and expertise to perform the examination in clinical practice. Studies have shown that effective teaching and enhanced confidence in ability requires both the use of a wide variety of instruction techniques as well as increased performance frequency $(3,6)$.

The present study was an analysis of the current practices in DRE teaching and evaluation in undergraduate medicine programs in schools across Canada. It aims to provide a comprehensive review of the methodologies used for teaching the DRE, the amount of time students spend practicing their skills and the types of evaluation methods used to assess proficiency in performing the DRE to identify possible areas for future curriculum improvement.

Schulich School of Medicine and Dentistry, Department of Gastroenterology, University of Western Ontario, London, Ontario

Correspondence: Dr Nilesh Chande, Schulich School of Medicine and Dentistry, Department of Gastroenterology, Victoria Hospital, Room E1-423A, 800 Commissioners Road East, London, Ontario N6A 5A5. Telephone 519-667-6582, fax 519-667-6820,

e-mail nilesh.chande@lhsc.on.ca

Received for publication June 13, 2011. Accepted September 6, 2011 


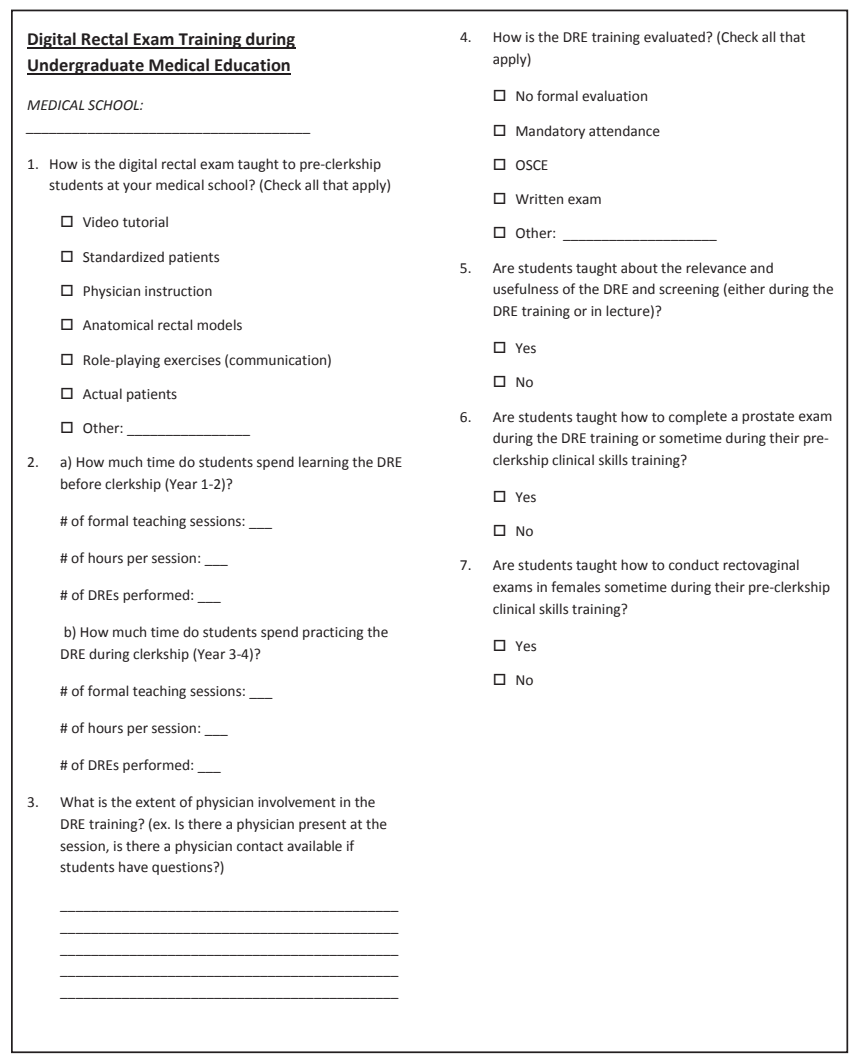

Figure 1) Study questionnaire completed by clinical skills coordinators at each medical school. DRE Digital rectal exam; OSCE Observed Standardized Clinical Exam

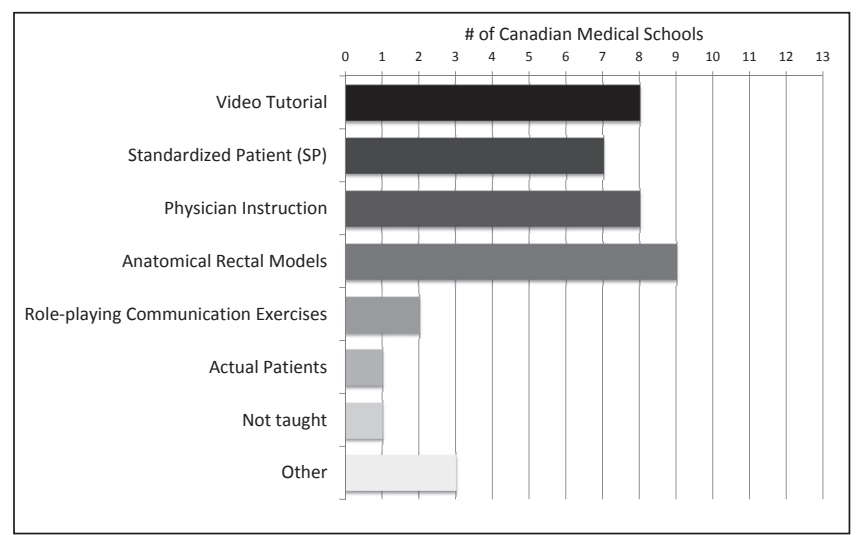

Figure 2). Summary of methods used to teach the digital rectal examination to preclerkship students in Canadian medical schools

\section{METHODS}

Undergraduate medicine clinical skills coordinators from the 14 Englishspeaking medical schools in Canada were invited to participate in the survey (Figure 1) and respond to questions regarding DRE teaching at their respective schools.

The questionnaire aimed to collect the qualitative and quantitative details of each school's clinical skills sessions during which students were taught how to conduct DREs, including prostate and rectovaginal examinations. Information about clinical skills training during both preclerkship and clerkship was obtained. Respondents were given the option of completing the survey online, by telephone or to decline to participate.

\section{RESULTS}

Survey responses were obtained from clinical skills coordinators from 13 of 14 (93\%) of the English-speaking medical schools in Canada.

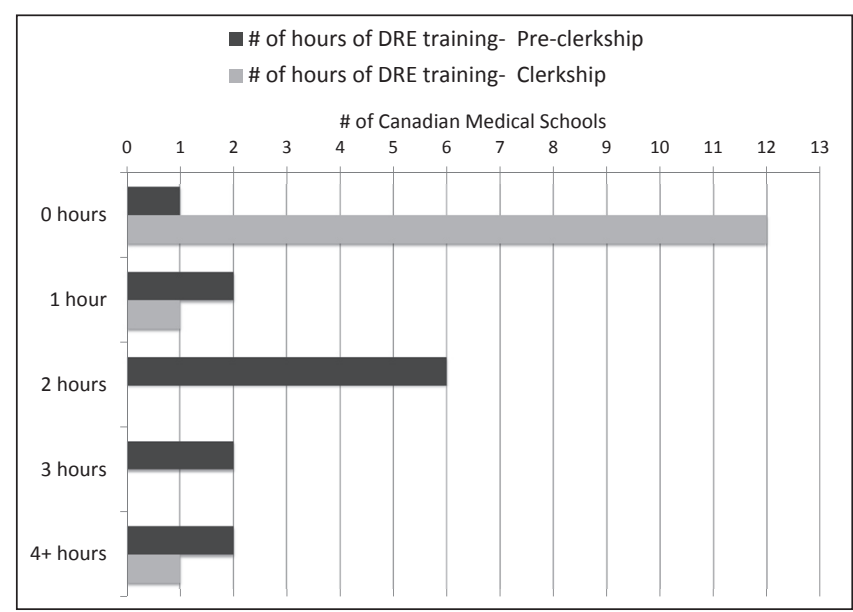

Figure 3) Length of time spent on digital rectal examination (DRE) training during preclerkship and clerkship years in Canadian medical schools

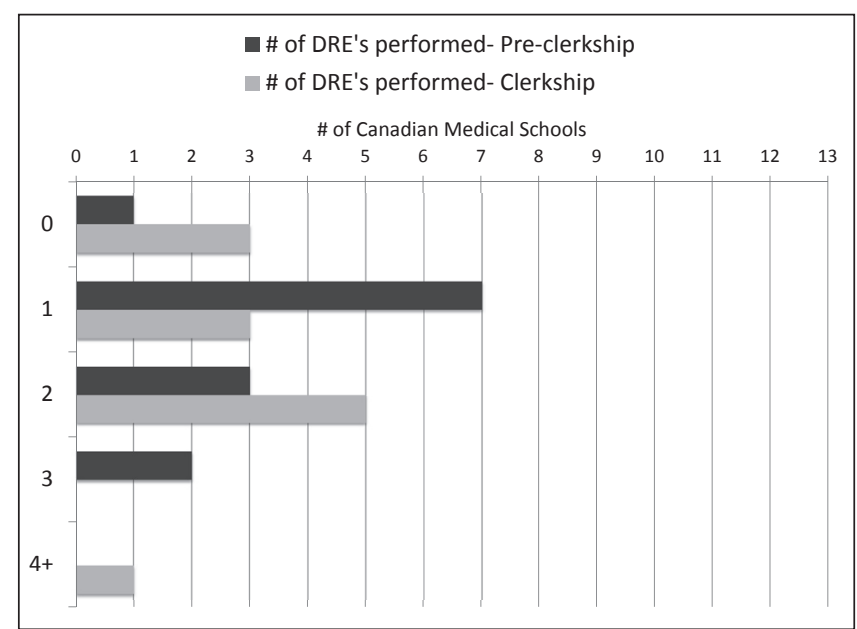

Figure 4) Number of digital rectal examinations (DREs) during preclerkship and clerkship years in Canadian medical schools

The DRE is taught to preclerkship students in various combinations of methods across the country (Figure 2), with many schools using visual and kinetic teaching aids in addition to theoretical instruction. Some other reported teaching techniques included urologic teaching assistants for male examinations and pelvic teaching assistants for female examinations.

Before starting clerkship, most of the schools surveyed (85\%) offer one formal teaching session as part of their clinical skills curriculum. Combined with the information regarding length of time of the teaching sessions, this was equivalent to a mean of approximately $2.15 \mathrm{~h}$ of DRE training during preclerkship. Most schools surveyed did not offer a formal DRE teaching session during clerkship (Figure 3). Preclerkship students in $62 \%$ of the schools performed one or fewer DREs during their training, and clinical skills coordinators in $85 \%$ of schools expected that clerkship students performed two or fewer (Figure 4).

DRE proficiency is evaluated in a variety of ways across the country (Figure 5). Most of the schools surveyed require mandatory attendance to the formal teaching sessions during preclerkship (77\%), with some schools including assessment of DRE training during written examinations or on anatomical rectal models as part of their Observed Standardized Clinical Exam. Three medical schools (23\%) surveyed have no formal evaluation of their DRE training.

Most of the medical schools surveyed include teaching about the clinical usefulness of the DRE and prostate examination in their preclerkship curriculum (92\%), and all of the schools surveyed teach their students how to complete a prostate examination at some point during their preclerkship clinical skills training. Approximately one-half of 
the schools surveyed reported that they taught the specialized skills of female rectovaginal examinationss before clerkship (54\%), while the rest of the schools reported that it is taught as part of their obstetrics and gynecology or family medicine clerkship rotations.

A summary of survey responses grouped according to medical school is presented in Table 1.

\section{DISCUSSION}

The DRE is taught to preclerkship medical students in Canada using a variety of methods. Most schools provided one formal DRE teaching session before clerkship and do not offer formal DRE training during clerkship. Methods of evaluation of the DRE training were also variable across the country, with most of the schools simply requiring mandatory attendance at the sessions and very few performing any formal evaluation. Information about the theoretical usefulness of the DRE and prostate screening was included in most of the medical school curriculums.

A study by Popadiuk et al (3), comparing the effectiveness of a variety of teaching methods for the DRE, found that a combination of lecture and teaching-assistant instruction was more effective and more preferred by students than any of the other teaching methods in isolation. Effective DRE teaching requires a multifaceted approach, using a

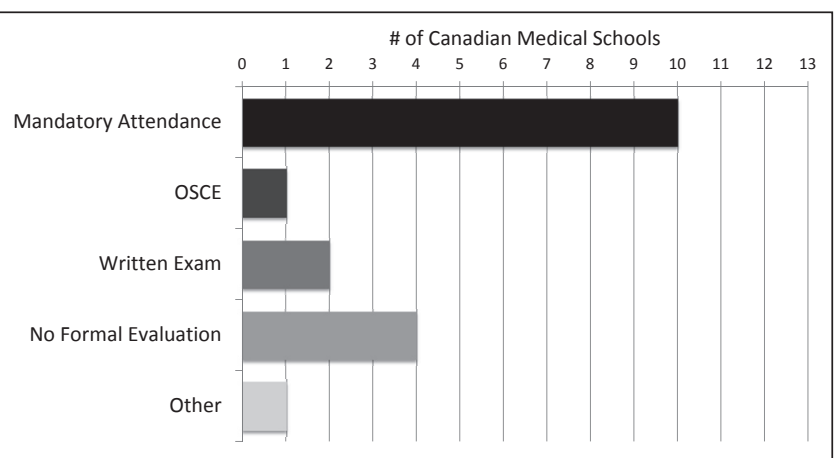

Figure 5) Methods used to evaluate digital rectal examination training during preclerkship in Canadian medical schools. OSCE Observed Standardized Clinical Exam

wide variety of teaching techniques to address all aspects of the examination. This includes models and videos for technique, physician instruction for theoretical knowledge and standardized patients to allow for feedback on examination technique, improvement of interpersonal communication skills and comfort performing the procedure.

TABLE 1

Summary of questionnaire results grouped according to medical school

\begin{tabular}{|c|c|c|c|c|c|}
\hline Medical school & How is the DRE taught to preclerkship students? & $\begin{array}{l}\text { DRE training } \\
\text { during medical } \\
\text { school, } \mathrm{h}\end{array}$ & $\begin{array}{c}\text { DREs } \\
\text { performed } \\
\text { during medical } \\
\text { school, } \mathbf{n}\end{array}$ & $\begin{array}{c}\text { How is the DRE } \\
\text { training evaluated } \\
\text { during } \\
\text { preclerkship? }\end{array}$ & $\begin{array}{c}\text { Are students taught } \\
\text { about the relevance } \\
\text { and usefulness of } \\
\text { the DRE? }\end{array}$ \\
\hline $\begin{array}{l}\text { Dalhousie } \\
\text { University, Halifax, } \\
\text { Nova Scotia }\end{array}$ & $\begin{array}{l}\text { Video tutorial, standardized patients, physician instruction, } \\
\text { anatomical rectal models, role-playing exercises }\end{array}$ & $\geq 4$ & 2 & $\begin{array}{l}\text { Mandatory } \\
\text { attendance, written } \\
\text { examination }\end{array}$ & Yes \\
\hline $\begin{array}{l}\text { McGill University, } \\
\text { Montreal, Quebec }\end{array}$ & Video tutorial, standardized patients, physician instruction & 2 & 2 & $\begin{array}{l}\text { Mandatory } \\
\text { attendance }\end{array}$ & Yes \\
\hline $\begin{array}{l}\text { McMaster University, } \\
\text { Hamilton, Ontario }\end{array}$ & $\begin{array}{l}\text { Video tutorial, physician instruction, anatomical rectal } \\
\text { models }\end{array}$ & 1 & 4 & $\begin{array}{l}\text { Mandatory } \\
\text { attendance }\end{array}$ & Yes \\
\hline $\begin{array}{l}\text { Memorial University, } \\
\text { St John's } \\
\text { Newfoundland }\end{array}$ & Standardized patients & 2 & 1 & $\begin{array}{l}\text { No formal evaluation, } \\
\text { mandatory } \\
\text { attendance }\end{array}$ & No \\
\hline $\begin{array}{l}\text { Northern Ontario School } \\
\text { of Medicine, Sudbury, } \\
\text { Ontario }\end{array}$ & $\begin{array}{l}\text { Standardized patients, anatomical rectal models, pelvic } \\
\text { teaching assistants for females }\end{array}$ & $\geq 4$ & 3 & $\begin{array}{l}\text { Mandatory } \\
\text { attendance }\end{array}$ & Yes \\
\hline $\begin{array}{l}\text { Queen's University, } \\
\text { Kingston, Ontario }\end{array}$ & $\begin{array}{l}\text { Video tutorial, standardized patients, physician instruction, } \\
\text { anatomical rectal models }\end{array}$ & 2 & 2 & $\begin{array}{l}\text { Mandatory } \\
\text { attendance }\end{array}$ & Yes \\
\hline $\begin{array}{l}\text { University of Alberta, } \\
\text { Edmonton, Alberta }\end{array}$ & Anatomical rectal models & 2 & 2 & No formal evaluation & Yes \\
\hline $\begin{array}{l}\text { University of British } \\
\text { Columbia, Vancouver, } \\
\text { British Columbia }\end{array}$ & Physician instruction, anatomical rectal models & 2 & 3 & $\begin{array}{r}\text { OSCE written } \\
\text { examination }\end{array}$ & Yes \\
\hline $\begin{array}{l}\text { University of Calgary, } \\
\text { Calgary, Alberta }\end{array}$ & $\begin{array}{l}\text { Video tutorial, standardized patients, anatomical rectal } \\
\text { models }\end{array}$ & 2 & 2 & $\begin{array}{l}\text { Mandatory attendance, } \\
\text { standardized patient } \\
\text { checklist }\end{array}$ & Yes \\
\hline $\begin{array}{l}\text { University of Manitoba, } \\
\text { Winnipeg, Manitoba }\end{array}$ & $\begin{array}{l}\text { Video tutorial, standardized patients, physician instruction, } \\
\text { role-playing exercises, actual patients }\end{array}$ & 3 & 3 & $\begin{array}{l}\text { Mandatory } \\
\text { attendance }\end{array}$ & Yes \\
\hline $\begin{array}{l}\text { University of Ottawa, } \\
\text { Ottawa, Ontario }\end{array}$ & $\begin{array}{l}\text { Video tutorial, physician instruction, anatomical rectal } \\
\text { models }\end{array}$ & 3 & $\geq 4$ & $\begin{array}{l}\text { No formal evaluation, } \\
\text { mandatory } \\
\text { attendance }\end{array}$ & Yes \\
\hline $\begin{array}{l}\text { University of } \\
\text { Saskatchewan, } \\
\text { Saskatoon, } \\
\text { Saskatchewan }\end{array}$ & Not currently taught at the preclerkship level & 0 & $\geq 4$ & No formal evaluation & Yes \\
\hline $\begin{array}{l}\text { University of Western } \\
\text { Ontario, London, } \\
\text { Ontario }\end{array}$ & $\begin{array}{l}\text { Video tutorial, standardized patients, physician instruction, } \\
\text { anatomical rectal models }\end{array}$ & 2 & 3 & $\begin{array}{l}\text { Mandatory } \\
\text { attendance }\end{array}$ & Yes \\
\hline
\end{tabular}


While our results indicate that many medical schools do offer a formal training session using a wide variety of teaching methods, it is also apparent that medical students do not have the opportunity to actually perform a DRE very frequently during their undergraduate training. In addition, most schools only require attendance at training sessions and do not administer a proficiency-based type of evaluation to assess the skills developed during teaching. Previous studies have shown that medical students' confidence in their ability to perform a DRE and identify malignancy is correlated with the number of DREs they performed (6), and our results show that students are performing very few before they graduate. During preclerkship, students generally undergo only one training session, and during clerkship the number of DREs performed is likely dependent on whether a supervisor is willing to teach and whether the clerk is sufficiently comfortable to perform it. While previous research has shown that clinical skills training using a wide variety of methods is a very effective teaching tool $(8,9)$, it appears that students are not developing the competence or experience to translate their knowledge of the examination into practice.

The response rate to our survey $(92.8 \%)$ was highly satisfactory; however, limitations of the present study revolve mainly around the accuracy of the responses to our survey by the clinical skills coordinators at each of the schools. It is possible that the actual practice and delivery of curriculum objectives could differ from what is mandated. In addition, as mentioned above, experiences during clerkship are more supervisor-dependent than preclerkship training and, therefore, more variable (10). Similar to other studies using questionnaires that have not been externally validated, unknown limitations may exist based on question selection or scope (11).

It is our recommendation that DRE training should be given the same priority and importance as other clinical skills taught as part of the undergraduate medical education curriculum with regard to number of practice sessions and formal evaluation of proficiency. Similar to the way in which other physical examination skills are

\section{REFERENCES}

1. Lim CH, Quinlan DM. Are doctors examining prostates in university hospital? Urology 2007;70:843-5.

2. Freeman HJ. Documentation of rectal examination performance in the clinical teaching unit of a university hospital.

Can J Gastroenterol 2000;14:272-6.

3. Popadiuk C, Pottle M, Curran V. Teaching digital rectal examinations to medical students: An evaluation study of teaching methods. Acad Med 2002;77:1140-6.

4. Fitzgerald D, Connolly SS, Kerin MJ. Digital rectal examination: National survey of undergraduate medical training in Ireland. Postgrad Med J 2007;83:599-601.

5. Balkissoon R, Blossfield K, Salud L, Ford D, Pugh C. Lost in translation: Unfolding medical students' misconceptions of how to perform a clinical digital rectal examination. Am J Surg 2009;197:525-32.

6. Hennigan TW, Franks PJ, Hocken DB, Allen-Mersh TG. Influence of undergraduate teaching on medical students' attitudes to rectal examination. BMJ 1991;302:829. taught, we recommend that the topic should be introduced with a formal lecture followed by a session during which students can practice on standardized patients with physician supervision. Students should have additional opportunities to practice this skill on standardized patients during clinical skills sessions in preclerkship training. Their technique and ability to detect pathology should be examined during the preclerkship Observed Standardized Clinical Exam. In addition, students should be encouraged to perform as many DREs as possible on real patients during clerkship, including some with physician supervision to confirm the technique and findings. This is the same way in which other skills, such as taking blood pressure or conducting a cardiac examination, are taught and evaluated in Canadian medical schools. Changing the curriculum to include DRE as one of the clinical skills that is taught repeatedly and evaluated objectively will ensure that students are just as proficient with this manoeuvre as with other clinical skills at the time of graduation.

\section{CONCLUSION}

The present study demonstrated that while a broad range of techniques are used to teach and evaluate DRE training in Canadian medical schools, students are not actually performing very many examinations before they graduate. Moreover, students are required to attend the training sessions, but are not given proficiencybased evaluation afterward. Students who get more practice and are more comfortable performing rectal examinations during their training are more likely to continue performing them during their clinical practice (6). For this reason, it is imperative that medical schools objectively evaluate proficiency to give meaningful feedback and improve competence in their students while also providing more opportunities for students to obtain the necessary experience performing DRE during clinical training.

7. Dakum K, Ramyil VM, Agbo S, Ogwuche E, Makama BS, Kidmas AT. Digital rectal examination for prostate cancer: Attitude and experience of final year medical students. Niger J Clin Pract 2007;10:5-9.

8. Barnard A, Owen C, Tyson A, Martin S. Maximising student preparation for clinical teaching placements. Clin Teach 2011;8:88-92.

9. Nishigori H, Masuda K, Kikukawa M, et al. A model teaching session for the hypothesis-driven physical examination. Med Teach 2011;33:410-7.

10. Remmen R, Derese A, Scherpbier A, et al. Can medical schools rely on clerkships to train students in basic clinical skills? Med Educ 1999;33:600-5.

11. Armstrong D, Ashworth M. When questionnaire response rates do matter: A survey of general practitioners and their views of NHS changes. Br J Gen Pract 2000;50:479-80. 


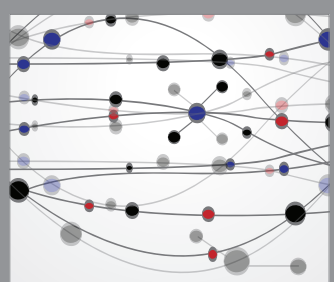

The Scientific World Journal
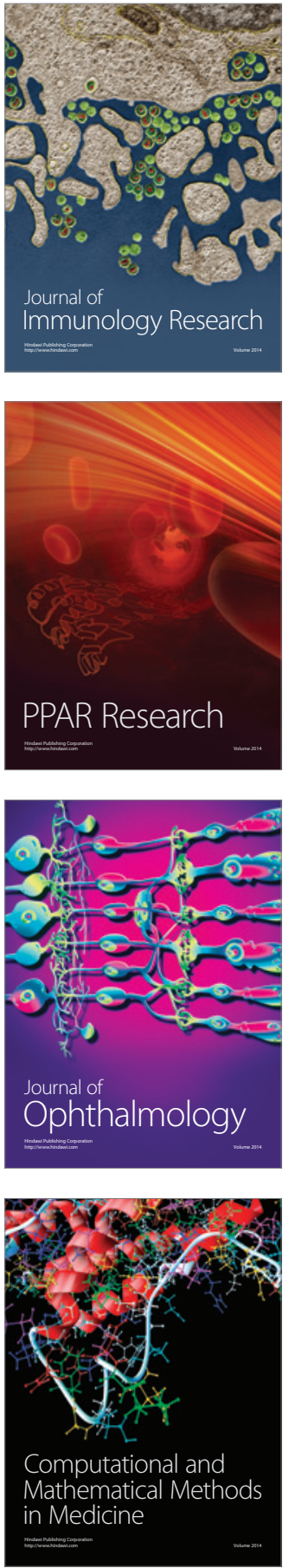

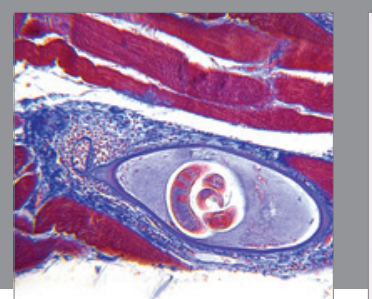

Gastroenterology Research and Practice

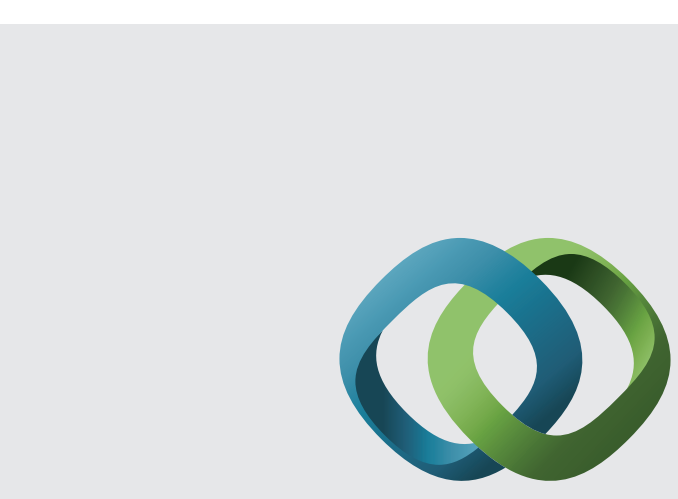

\section{Hindawi}

Submit your manuscripts at

http://www.hindawi.com
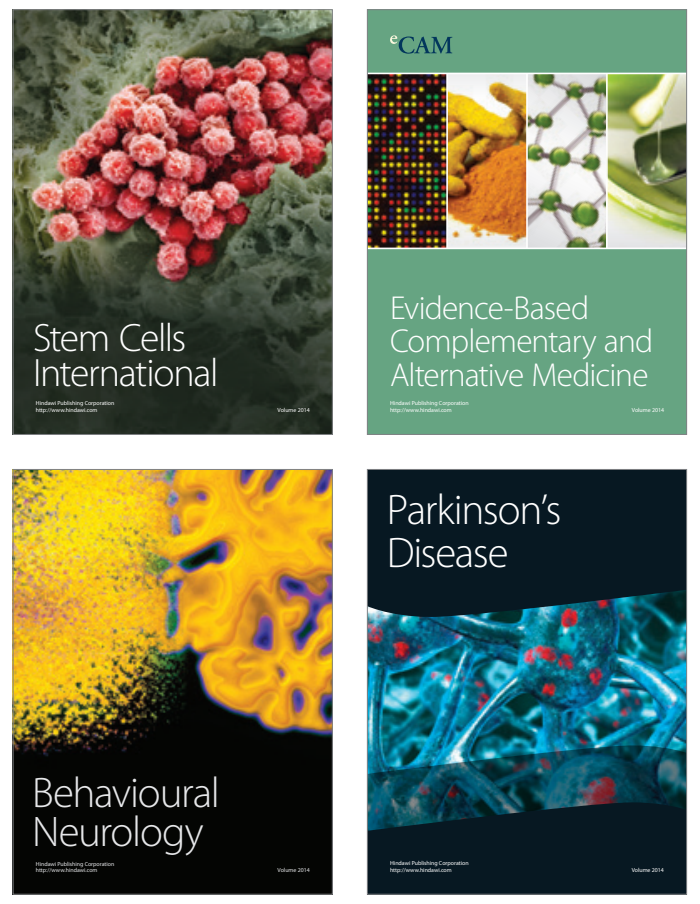
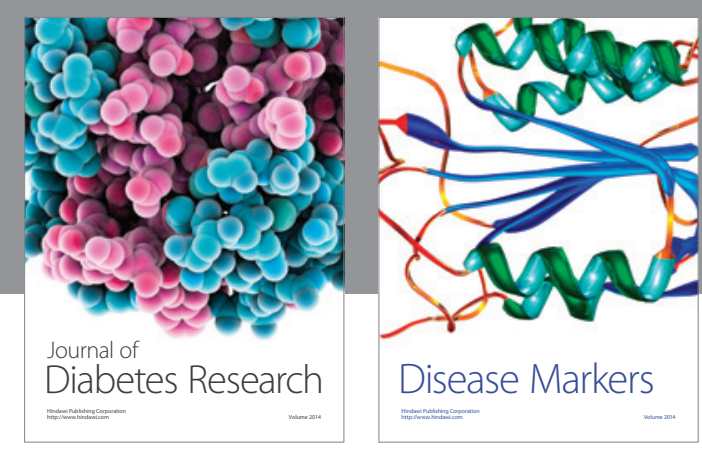

Disease Markers
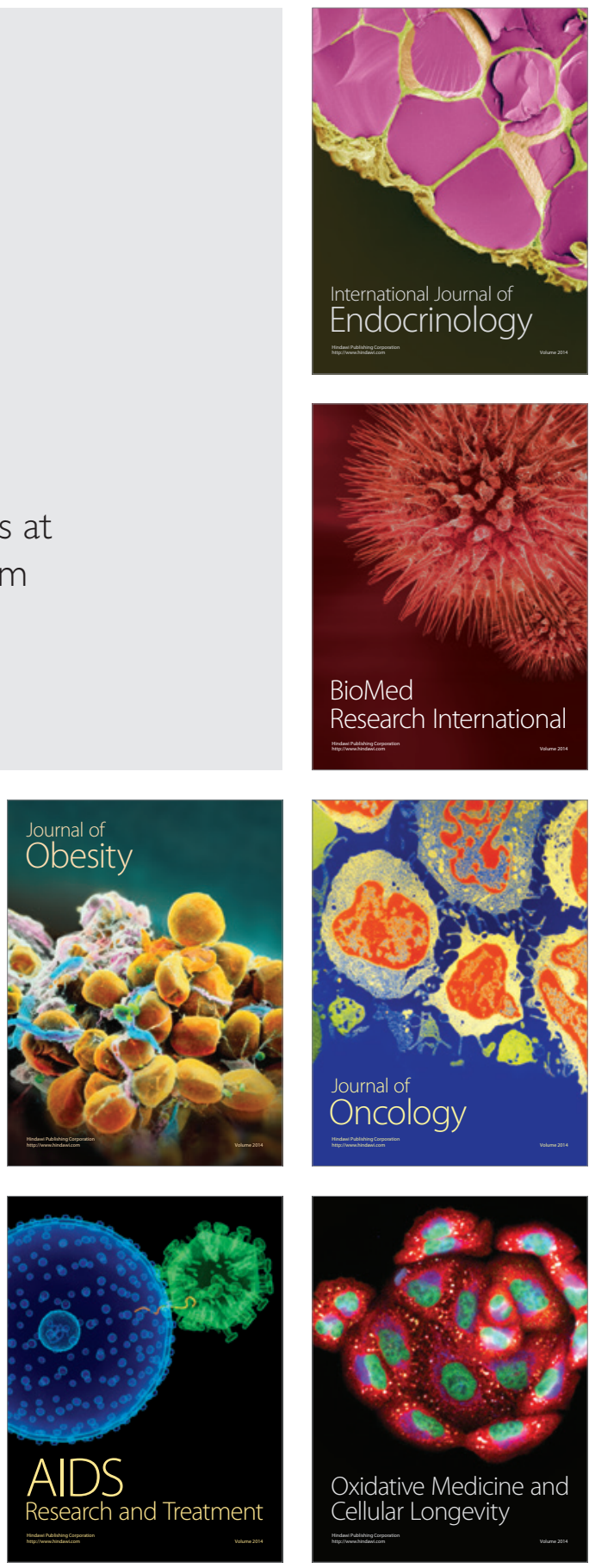